\title{
Development of feeding skills in preterm infants: a critical literature review
}

\section{Desarrollo de habilidades de alimentación en niños prematuros:} una revisión crítica de la literatura

María Angélica Fernández Gallardo(1) Daniela Paz Rojas Contreras ${ }^{(1)}$ Javiera Francisca Vargas Keith ${ }^{(1)}$

(1) Departamento de Fonoaudiología, Universidad de Chile, Santiago, Chile.

Conflict of interest: non-existent

Received on: April 13, 2017

Accepted on: July 26, 2017

Mailing address:

María Angélica Fernández G.

Av. Independencia 1027, Independencia,

Santiago, Chile

E-mail:ma_fernandez@med.uchile.cl

\section{ABSTRACT}

Infants born prematurely have problems in developing feeding skills due to their immaturity. To describe this, a critical review of national and international literature was carried out from May to September 2016. The information was reviewed from Scielo, Pubmed and Cochrane, and also specialized journals using the following key words: "Feeding development preterm", "feeding skills preterm infants", "feeding transition preterm", "lumpy food babies", "solid food preterm", "transition solid food infant", "preterm children weaning food", "solids in preterm infants", also searched in Spanish and Portuguese. Publications were included if they shared similar purpose as the present revision, and published in the last 5 years, encompassing articles of systematic literature review or researches which studied preterm children aged between 0 and 10. Studies showed that transition food started earlier in preterm infants, who also showed more feeding problems. It is necessary to have common criteria in terms of assessment methodologies in order to be able to characterize this group in a better way. Parents of preterm infants would benefit from advise and information about developing eating skills, resulting in earlier intervention and management of feeding and eating problems.

Keywords: Infant, Premature; Supplementary Feeding; Assessment

\section{RESUMEN}

Debido a la inmadurez que presentan los lactantes prematuros, el desarrollo de habilidades de alimentación se ve interferido. Mediante la revisión sistemática de la literatura internacional y nacional se intentó describir este proceso. Se realizó una búsqueda entre mayo y septiembre del 2016 en Scielo, Pubmed y Cochrame y revistas especializadas utilizando los descriptores: "Feeding development preterm", "feeding skills preterm infants", "feeding transition preterm", "lumpy food babies", "solid food preterm", "transition solid food infant", "preterm children weaning food", "solids in preterm infants", tanto en español como en portugués. Se consideraron publicaciones que tuvieran directa relación con el objetivo de esta revisión realizadas en los últimos 5 años, artículos de revisión sistemática de la literatura 0 investigaciones experimentales cuyo objeto de estudio fueran niños prematuros entre 0 y 10 años. Las investigaciones mostraron que la incorporación de consistencias es más temprana en niños prematuros que de término y que presentan mayores dificultades de alimentación. Se requiere aunar criterios en cuanto a metodologías de evaluación para poder caracterizar a este grupo de mejor manera. Padres y cuidadores de prematuros requieren manejar información completa en relación a la alimentación complementaria para que esta sea exitosa, logrando una pesquisa oportuna y un adecuado manejo.

Descriptores: Prematuro; Alimentación Complementaria; Evaluación 


\section{INTRODUCTION}

Premature birth continues to be the leading cause of mortality in newborns (infants in their first four weeks of life) ${ }^{1}$. However, due to the advances in technology, survival of the preterm population has increased significantly worldwide because of the reduction of neonatal morbidity and mortality ${ }^{2}$. A preterm newborn is one born before 37 weeks of gestation and extremely preterm infants are those born with less than 32 weeks of gestation ${ }^{1,3}$. In Chile, preterm newborns account for $7.3 \%$ of total births and $1.2 \%$ correspond to extremely preterm infants.

Due to the immaturity presented by preterm infants, their whole development is affected, including their feeding process ${ }^{4}$. At first, the feeding is in most cases non-oral with an impaired suck-swallow mechanism. Although this initial impairment is described in the literature, the way the feeding process continues to develop in later stages of childhood has not been studied in depth, for example when other types of consistencies are introduced into the diet ${ }^{5}$.

Regarding the age at which solid foods have to be introduced, there are different views, appearing to be a controversial issue. On one hand, the World Health Organization (WHO) recommends breastfeeding as the sole method of feeding until six months of age, and to start supplementing with other type of foods from this age, maintaining breastfeeding until two years old or more ${ }^{6}$. The American Academy of Pediatrics (AAP) has a similar view, recommending like the WHO, exclusive breastfeeding until six months old. However, the European Society of Pediatric Gastroenterology, Hepatology and Nutrition, indicates that the introduction should not occur before 4 months nor after 6 months of age. No more specific recommendations are made for the case of preterm infants, and most literature suggests that given the lack of consensus and evidence, the decision to transition to more solid foods in preterm infants should be made according to individual characteristics ${ }^{7}$.

In spite of the above, a significant number of studies were found in literature suggesting, that in preterm infants, solid foods are introduced even before 4 months, as mentioned in Braid et al. ${ }^{7}$, Rodrigues and Delgado ${ }^{8}$, Jonsson et al. ${ }^{9}$ and Chung et a ${ }^{10}$.

In Chile, the recommendation is to begin introducing supplementary feeding after six months, incorporating foods of puree or pudding consistency with no lumps; between 8 and 10 months thicker porridge consistencies have to be added until reaching 12 months old, when ground food is added, at 18-20 months chopped consistency and after 24 months, most children can eat the same type and consistency of food as the rest of the family ${ }^{11,12}$.

Considering that preterm infants are at greater risk of developing feeding or nutritional disorders and have lower physical growth compared to their full-term peers, it is important to have information on how feeding skills are developed and which factors can favor or difficult them ${ }^{8}$.

The aim of this research was to perform a systematic review of international and national literature in order to describe the development of feeding skills in preterm infants.

\section{METHODS}

A literature survey was conducted in the following databases: Scielo, Pubmed and Cochrame. Search was also made in specialized journals such as Revista CEFAC, American Journal of Clinical Nutrition, Pediatrics and The Journal of Pediatrics. Articles were selected from these sources, also because of their easy access and their validity in academic world. In a more targeted way, 2 studies were identified from the bibliographic reference in the selected articles.

The key words that were used were: Feeding development preterm, feeding skills preterm infants, feeding transition preterm, lumpy food babies, solid food preterm, transition solid food infant, preterm children weaning food, solids in preterm infants. These descriptors were searched both in Spanish and Portuguese.

An initial selection was made of a series of potentially relevant articles, from their titles and abstracts, reviewed by at least two independent researchers. Articles were only included if at least two researchers deemed them as useful for this study. Complete text was analyzed when the studies appeared to highly related with chosen topic.

The search was conducted between May and September of 2016 and yielded a total of 51, 1194 and 6805 articles in Scielo, Pubmed and Cochrane respectively, the distribution of which, according to descriptor and database, can be seen in Table 1. 
Table 1. Distribution of articles according to the descriptors and database used

\begin{tabular}{cccc}
\hline Descriptors/Keywords & Scielo & Pubmed & Cochrame \\
\hline Feeding development preterm & 20 & 890 & 2,423 \\
Feeding skills preterm infants & 12 & 133 & 1,048 \\
Feeding transition preterm & 18 & 133 & 558 \\
Lumpy food babies & 0 & 7 & 986 \\
Solid food preterm & 1 & 24 & 739 \\
Transition solid food infant & 0 & 7 & 1,051 \\
Preterm children weaning food & 0 & 16 & 1,796 \\
Solids in preterm infants & 0 & 38 & 6,750 \\
\hline TOTAL: & 51 & 1,194 & 6,805 \\
\hline
\end{tabular}

\section{Inclusion criteria}

After the first stage of text selection, a second stage was conducted based on, the following inclusion criteria:

- Publications not older than 5 years, so that final studies had been published between 2012 and 2016.

- Systematic literature reviews or experimental researches. In the case of experimental studies, age for preterm sampled infants had to be withun $0-10$ years range.

- Studies had to be directly related to the objective of the present review.

\section{Exclusion criteria}

Articles with one or more of the following characteristics were excluded:
- Theoretical reviews of literature.

- Studies of children born full-term.

- Studies outside the selected period (January 2012 to September 2016).

- Repeated articles.

- Articles with topics otherthan this review's scope.

- Articles that were not available in full text

12 articles were finally selected complying with adopted criteria. Table 2 shows the distribution of the articles according to descriptors and database.

For subsequent analyzes, selected articles were organized in an spreadsheet file including, which indicated title, year, authors, methodological specifications and results of each of them, to enable a comparative analysis.

Table 2. Distribution of selected articles according to the descriptors and database used

\begin{tabular}{cccc}
\hline Descriptors/Keywords & Scielo & Pubmed & Cochrane \\
\hline Feeding development preterm & 2 & 3 & 0 \\
Feeding skills preterm infants & 0 & 3 & 0 \\
Feeding transition preterm & 0 & 0 & 0 \\
Lumpy food babies & 0 & 0 & 0 \\
Solid food preterm & 0 & 2 & 0 \\
Transition solid food infant & 0 & 0 & 0 \\
Preterm children weaning food & 1 & 0 & 0 \\
Solids in preterm infants & 0 & 1 & 0 \\
\hline
\end{tabular}




\section{LITERATURE REVIEW}

Table 3 describes, 12 articles analyzed in this research indicating authors, year of publication, type of study, mean of assessing feeding and age of assessment of preterm infants.

The way to collect information about the feeding process in preterm infants was through the compilation of the children's health records, parent questionnaire, direct assessment/observation of the feeding process in children or a combination of procedures such as questionnaire to parents/caregivers about feeding skills along with direct assessment to children.

In $75 \%(9 / 12)$ of selected articles, information gathered through questionnaires for parents. It should be noted that these investigations used different questionnaires, which in turn assessed various aspects of the feeding process.

Of the 12 articles analyzed, 5 examined children aged 24 months or more, through questionnaires for parents. Investigations studied children between 8 and 12 months and obtained information from different data sources (questionnaire to parents and residents, among others), but unlike the studies performed in children aged 24 months or more, they also performed an assessment and/or direct observation of the child. In two investigations the assessment was conducted with another method. Crapnell et al..$^{13}$ assessed preterm infants at an initial stage through a parent questionnaire and at 24 months, performing a direct assessment. Finally, Chung et al. ${ }^{10}$ assessed the perception of parents with regard to the feeding process of their children, who were between 2 and 23 months old, only through questionnaires.

It should be noted that cross-sectional studies and the assessment of feeding through questionnaires to parents, requesting different information about the feeding process of the child, were predominant among selected articles. This was generally done retrospectively, which could generate a limitation in the accuracy of the reported data, because it depends directly on factors such as parental memory.

Johnson et al. ${ }^{14}$ used a validated questionnaire on eating behavior that assesses four important aspects: food rejection/selectivity, oral motor difficulties, oral hypersensitivity, and eating behavior disorders. In the same line, Crapnell et al. in $2013^{13}$ and $2015^{15}$, applied a questionnaire to parents of 2-year-old preterm infants using the Infant-Toddler Social Emotional Assessment (ITSEA) Eating Subscale. This scale evaluates typical (difficulty accepting new foods, among others) and atypical (spitting food, gag reflex or choking, for example) eating behavior. Parents had to categorize the behavior of the child in relation to the frequency with which it was presented.

In Chung et al. $^{10}$ a questionnaire was used that measured how "ready" children are in development, along with avoidant eating behaviors. Parents were asked about what difficulties their children presented when introducing more solid foods (suction or swallowing problems, choking, crying, among others).

Nieuwenhuis et al. $^{16}$ used the Screeningslijst Eetgedrag Peuters (SEP), which is a validated Dutch version of the Montreal Children's Hospital Feeding Scale. This questionnaire consisted of 14 items that reflected symptoms that could be present in the feeding process, like oral motor behaviors or oral sensorial behaviors and appetite. It also included aspects like parents' concerns about feeding, mealtime, and strategies used by parents and family to deal with the infant's behaviors. Similarly, Migraine et al. ${ }^{17}$ used another questionnaire validated in France, "Children's Eating Difficulties Questionnaire", which evaluated 4 dimensions: neophobia, selectivity, poor appetite and enjoyment of food. In addition, another questionnaire was used to collect information regarding the frequency of food intake and preference, which was applied in parents of 2-year-old infants.

Jonsson et al. ${ }^{9}$ applied a self-created questionnaire, which was based on the literature available to date on the skills and development of feeding in the first 3 years of life ${ }^{18,19}$. The questionnaire consisted of 4 sections: general information (gender, weeks of gestation, weight, among others), information about feeding while the child was in the hospital (non-oral feeding, transition to oral feeding among other aspects), Parents' experiences of home-based meals (from discharge to the introduction of more solid foods), and lastly, the child's eating habits at 3 years old approximately.

In summary, a diverse range of questionnaires were used, validated, adapted or created for research purposes. All of them assessed the child's eating behavior, emphasizing different aspects following researchers'interests. Only a few ones included topics such as experience/feelings of the parents regarding their children's' feeding process.

Another method of collecting feeding-related information was through observing the feeding process at a given time. For example, Parker et al. ${ }^{20}$ assessed the feeder-child dyad in the feeding process through NCAFS, which is a validated instrument for both preterm 
Table 3. Selected articles' specification

\begin{tabular}{|c|c|c|c|}
\hline Article & Type of study & Mean of assessment & Age of assessment \\
\hline $\begin{array}{l}\text { Johnson S, Matthews R, Draper ES, Field DJ, Manktelow BN, } \\
\text { Marlow N, et al. Eating difficulties in children born late and } \\
\text { moderately preterm at } 1-32 \text { y of age: a prospective population- } \\
\text { based cohort study. The american Journal of clinical nutrition. } \\
\text { 2016; 103:403-14 }\end{array}$ & Cross-sectional & $\begin{array}{l}\text { Questionnaire filled out by } \\
\text { the parents }\end{array}$ & $\begin{array}{c}24 \text { months } \\
\text { corrected age }\end{array}$ \\
\hline $\begin{array}{l}\text { Crapnell TL, Woodward LJ, Rogers CE, Inder TE, Pineda } \\
\text { RG. Neurodevelopmental Profile, Growth, and Psychosocial } \\
\text { Environment of Preterm Infants with Difficult Feeding Behavior } \\
\text { at Age } 2 \text { Years. The Journal Of Pediatrics. 2015; 167(6): 1347- } \\
53\end{array}$ & Cross-sectional & $\begin{array}{l}\text { Questionnaire filled out by } \\
\text { the parents }\end{array}$ & 24 months \\
\hline $\begin{array}{l}\text { Chung J, Lee J, Spinazzola R, Rosen L, Milanaik R. Parental } \\
\text { perception of premature infant growth and feeding behaviors: } \\
\text { use of gestation-adjusted age and assessing for developmental } \\
\text { readiness during solid food introduction. Clin Pediatr (Phila). } \\
\text { 2014; 53(13): 1271-77. }\end{array}$ & Cross-sectional & $\begin{array}{l}\text { Questionnaire filled out by } \\
\text { the parents }\end{array}$ & $\begin{array}{l}2 \text { - } 23 \text { months } \\
\text { corrected age }\end{array}$ \\
\hline $\begin{array}{l}\text { Nieuwenhuis T, Verhagen EA, Bos AF, Van Dijk MW. Children } \\
\text { born preterm and full term have similar rates of feeding } \\
\text { problems at three years of age. Acta pediátrica. 2016; 1-6. }\end{array}$ & Cross-sectional & $\begin{array}{l}\text { Questionnaire filled out by } \\
\text { the parents }\end{array}$ & 36 months \\
\hline $\begin{array}{l}\text { Jonsson M, Doorn JV, Van den Berg J. Parents perceptions } \\
\text { of eating skills of pre-term vs full-term infants from birth to } \\
3 \text { years. International Journal of Speech-Language Pathology. } \\
2013 ; 16(6): 604-12 \text {. }\end{array}$ & Cross-sectional & $\begin{array}{l}\text { Questionnaire filled out by } \\
\text { the parents }\end{array}$ & 34-42 months \\
\hline $\begin{array}{l}\text { Crapnell TL, Rogers CE, Woodward MD, Neil JJ, Pineda RG. } \\
\text { Factors Associated with Infant Feeding Difficulties in the Very } \\
\text { Preterm Infant. Acta Paediatr. 2013; 102(12):539-45 }\end{array}$ & Longitudinal & $\begin{array}{l}\text { Direct assessment of } \\
\text { children and parents }\end{array}$ & $\begin{array}{l}24 \text { months } \\
\text { (children's } \\
\text { assessment) }\end{array}$ \\
\hline $\begin{array}{l}\text { Migraine A, Nicklaus S, Parnet P, Lange CH, Monnery-Patris S, } \\
\text { Des Robert C, et al. Effect of preterm birth and birth weight on } \\
\text { eating behavior at } 2 \text { y of age. Am J Clin Nutr. 2013; } 97: 1270-7 \text {. }\end{array}$ & Cross-sectional & $\begin{array}{l}\text { Questionnaire filled out by } \\
\text { the parents }\end{array}$ & $\begin{array}{l}24 \text { months } \\
\text { corrected age }\end{array}$ \\
\hline $\begin{array}{l}\text { Braid S, Harvey EM, Bernstein J, Matoba N. Early Introduction } \\
\text { of Complementary Foods in Preterm Infants. JPGN. 2015; } \\
\text { 60(6):811-818. }\end{array}$ & Cross-sectional & $\begin{array}{l}\text { Questionnaire filled out } \\
\text { by the parents and child } \\
\text { assessment }\end{array}$ & $\begin{array}{c}9 \text { months corrected } \\
\text { age }\end{array}$ \\
\hline $\begin{array}{l}\text { Parker M, Rybin D, Heeren TC, Thoyre SM, Corwin MJ. } \\
\text { Postdischarge Feeding Interactions and Neurodevelopmental } \\
\text { Outcome at 1-Year Corrected Gestational Age. The Journal Of } \\
\text { Pediatrics. 2016; 174:104-10. }\end{array}$ & Cross-sectional & $\begin{array}{l}\text { Observation of regular } \\
\text { feeding process by a } \\
\text { trained observer using a } \\
\text { validated instrument }\end{array}$ & $\begin{array}{l}12 \text { months } \\
\text { corrected age }\end{array}$ \\
\hline $\begin{array}{l}\text { Den Boer SL, Schipper JA. Feeding and drinking skills in preterm } \\
\text { and low birth weight infants compared to full term infants at } \\
\text { a corrected age of nine months. Early Human Development. } \\
2013 ; 89: 445-447 \text {. }\end{array}$ & Cross-sectional & $\begin{array}{l}\text { Observation of the } \\
\text { feeding process }\end{array}$ & $\begin{array}{c}9 \text { months corrected } \\
\text { age }\end{array}$ \\
\hline $\begin{array}{l}\text { Törölä H, Lehtihalmes M, Yliherva A, Olsén P. Feeding skill } \\
\text { milestones of preterm infants born with extremely low birth } \\
\text { weight(ELBW). Infant Behavior and Development. 2012; } \\
35: 187-94 \text {. }\end{array}$ & Longitudinal & $\begin{array}{l}\text { Reccorded sessions } \\
\text { were analyzed using the } \\
\text { NOMAS (Neona- tal Oral } \\
\text { Motor Assessment Scale) } \\
\text { scale and a oral motor } \\
\text { patterns checklist }\end{array}$ & $\begin{array}{l}37 \text { weeks } \\
\text { (corrected age - } \\
8 \text { months) }\end{array}$ \\
\hline $\begin{array}{l}\text { Rodrigues H, Delgado SL. Characterization of the feeding } \\
\text { development of preterm infants between three and twelve } \\
\text { months. Revista CEFAC. } 2014 ; 16(3): 917-27 \text {. }\end{array}$ & Cross-sectional & $\begin{array}{l}\text { Questionnaire filled out } \\
\text { by the parentsand child } \\
\text { assessment }\end{array}$ & 3-12 months \\
\hline
\end{tabular}


and full-term infants at nine months of corrected age, observing the feeder's behaviors as well as the child's in a unique feeding event. As for the feeder, it was possible to observe sensitivity and response to the child's signals of stress during the feeding process, among other aspects, and in the infant, the clarity of the signals towards the feeder and sensitivity towards the caregiver were observed. On the other hand, in the research carried out by den Boer and Schipper ${ }^{21}$, the assessment was conducted by a speech therapist applying a standardized checklist of behaviors related to drinking and eating.

A different approach can be observed in the study by Törölä et al..$^{22}$ because it performs a longitudinal study assessing the suction pattern through the Neonatal Oral Motor Assessment Scale (NOMAS), which categorizes the suction pattern in: Normal, Disorganized and Dysfunctional. In addition, a checklist adapted from the Pediatric Oral Skills Package was used to assess oral motor patterns during semisolids and solids feeding, along with a description of the feeding abilities, of Morris and $\mathrm{Klein}^{19}$. To collect information regarding the feeding development, video recordings were used when preterm infants were at 37 weeks of corrected age, at 40 weeks of corrected age, every two weeks up to 3 months of corrected age, and once a month until chewing skills appeared.

It would be interesting that future studies investigate the correlation between the direct assessment of the child's feeding process and questionnaires to parents or caregivers about this process, in addition to researching about aspects that could influence the assessment such as: parents' memories in relation to past situations, the stress of parents, the importance and knowledge regarding the feeding of their children.

\section{Age of incorporation of supplementary foods}

Of the selected articles, 4 investigations mentioned the age at which the most solid food was incorporated. Braid et al. ${ }^{7}$, Jonsson et al. ${ }^{9}$ and Rodrigues and Delgado ${ }^{8}$ report that the incorporation of supplementary feeding started earlier in preterm infants than in full-term infants (3.25 months of corrected age in preterm infants versus 4.25 to 4.5 months in full-term infants).

In Table 4, the average age at which solid foods are incorporated in full-term compared to preterm infants can be observed. Both ages are concordant between investigations. It is emphasized that preterm infants have an earlier incorporation of solid foods than full-term infants, which is inconsistent with the WHO recommendation to introduce solid foods between the ages of 6 and 9 months ${ }^{23}$. This, is surprising since incorporation of foods, besides being an important change in nutritional aspects, is associated with physiological maturation and development of the child, which would be different in full-term and preterm infants ${ }^{24}$. The consistency and variety of food is gradually increased as the child grows, adapting to their requirements and skills ${ }^{25}$. A similar recommendation is given by the Nutrition Branch of the Chilean Pediatric Society, who suggests the incorporation of more solid foods from 6 months of age in both exclusively breastfed infants and those who used formulas; However, it is pointed out that there is still insufficient evidence to indicate that these consistencies cannot be incorporated in the range of 5 to 6 months ${ }^{12}$.

Table 4. Average age of solid foods incorporation in full-term and pre-term infants

\begin{tabular}{|c|c|c|c|}
\hline \multicolumn{2}{|c|}{ Average age of solid foods incorporation } & \multirow{2}{*}{ Authors } & \multirow{2}{*}{ Publishing year } \\
\hline Pre-term infants & Full-term infants & & \\
\hline 3.25 months corrected age & 4.25 months old & $\begin{array}{l}\text { Braid S, Harvey EM, } \\
\text { Bernstein J, Matoba N. }\end{array}$ & 2015 \\
\hline 3.25 months corrected age & 4.25 months old & Rodrigues H, Delgado SL & 2014 \\
\hline 3.2 months corrected age & 4.5 months old & $\begin{array}{l}\text { Jonsson M, Doorn JV, } \\
\text { Van den Berg J }\end{array}$ & 2013 \\
\hline $3.9 \pm 2.1$ months corrected age & --------- & $\begin{array}{c}\text { Chung J, Lee J, Spinazzola R, } \\
\text { Rosen L, Milanaik R }\end{array}$ & 2014 \\
\hline
\end{tabular}


The type and consistency of foods used in the transition stage depend on the characteristics of the family group and its context. In many Latin American and otherdeveloping countries a large number of children consume at a very early age nutritionally inadequate foods, increasing the risk of growth retardation and pathologies, especially in preterm infants ${ }^{24}$.

The early onset of supplementary feeding may be due to arguments such as those presented in Coulthard $\mathrm{H}$ et al. ${ }^{23}$, where it is pointed out that early weaning (between 4 and 7 months) would be crucial in determining flavors and textures in children with barely one exposure to food, compared to later weaned children, who would need several food exposures to determine these characteristics.

\section{Feeding skills in preterm infants}

Jonsson et al. ${ }^{9}$ found that the most common feeding in the first 10 weeks of the hospitalization period in preterm infants was a combination of breastfeeding with tube feeding (50\%), followed by breastfeeding and bottle combined with non-oral feeding (22\%). The least common combination was bottle and tube (14\%). $44 \%$ of the parents reported that their child was not given breast milk when they were fed by tube, only $18 \%$ had been given milk to savor. $48 \%$ reported having had little oral stimulation with a pacifier. It should be considered that early oral experiences in patients with feeding difficulties, such as non-nutritive sucking, favor an earlier success in safe and successful feeding, in addition to reducing stress in hospitalized infants, increasing weight gain, and promoting gastrointestinal growth and maturation in preterm infants, and they allow a faster transition of tube to complete oral feeding ${ }^{26}$. At discharge, $44 \%$ of the infants were completely fed through breastfeeding. This fact should be worrisome due to the benefits of breastfeeding reported by the literature, such as its nutritional role, its effect in protection and development of the newborn and in the attachment between mother and child ${ }^{27}$. The reason could be, among others, that the extraction of milk from the breast is a much greater challenge than extracting milk from the bottle ${ }^{26}$.

Törölä et al. ${ }^{22}$ reported that, while they presented suckling (a more immature pattern), none of the preterm infants presented a normal sucking pattern (84.21\% disorganized pattern and $15.79 \%$ dysfunctional pattern). Despite this, both preterm and full-term infants reached a more mature pattern of suction at 2 months old. It should be taken into account that the disruption of the suction pattern may be indicative of a problem in the neurological development of the infant, therefore, prospective studies are required to determine if any diagnostic instrument could identify the necessary interventions, improving their prognosis ${ }^{25}$.

den Boer and Schipper ${ }^{21}$ reported that at 9 months old, $46 \%$ of preterm infants were able to drink independently from a bottle compared to $68 \%$ of the control group. They also found that $47 \%$ of preterm infants were able to eat bread with its crust, compared to $76 \%$ of the full-term children who did so.

As shown in Table 5, vertical chewing, "munching", appeared earlier in preterm infants (3 months of corrected age) compared to the appearance at 5 months in the full-term infants group. However, preterm infants needed 1.5 months to learn to handle semisolids properly while full-term infants learned instantaneously when semisolids were introduced. The different abilities of emergent chewing (lateral jaw movements, lateral tongue movements and diagonal movements) frequently appeared simultaneously. 
Table 5. Feeding skills in preterm infants

\begin{tabular}{|c|c|c|c|}
\hline Skills & Mean Age & Author & Year \\
\hline \multirow{4}{*}{ Breast-feeding } & $55.2 \%$ was not breastfed & \multirow{4}{*}{$\begin{array}{l}\text { Rodrigues } \mathrm{H} \text {, } \\
\text { Delgado SL }\end{array}$} & \multirow{4}{*}{2014} \\
\hline & $14.1 \% 1$ month & & \\
\hline & $19.3 \%$ 2-4 months & & \\
\hline & $11.4 \%>4$ months & & \\
\hline Voluntary suction & 2 months (1.5-3 months) & & \\
\hline Munching onset & 3 months corrected age (1.5-3 months range) & & \\
\hline $\begin{array}{l}\text { Emergent chewing: } \\
\text { lateral movements of the jaw }\end{array}$ & 5 months corrected age & & \\
\hline $\begin{array}{l}\text { Emergent chewing: } \\
\text { lateral movements of the tonque }\end{array}$ & 5 months corrected age & & \\
\hline $\begin{array}{l}\text { Emergent chewing: } \\
\text { diagonal movements }\end{array}$ & $\begin{array}{l}6 \text { months diagonal movements (2.5-7 months } \\
\text { rang). The average age in full-term infants } \\
\text { was } 5 \text { months (5-8 months range). }\end{array}$ & $\begin{array}{c}\text { Törölä H, } \\
\text { Lehtihalmes } M, \\
\text { Yliherva A, Olsén P }\end{array}$ & 2012 \\
\hline Diagonal rotary movements & $\begin{array}{l}7 \text { months average age (5-9 months range for } \\
\text { prematures and } 7-10 \text { months for full-term). }\end{array}$ & & \\
\hline Circular rotary movements & $\begin{array}{l}8 \text { months in both groups }(7-10 \text { months range } \\
\text { in preterm infants and } 7-11 \text { months range } \\
\text { in full-term infants) }\end{array}$ & & \\
\hline
\end{tabular}

\section{Difficulties experienced by preterm infants in feeding}

Overall, Jonsson et al. ${ }^{9}$ found that $48 \%$ of the parents of preterm infants report some kind of difficulty in feeding at discharge from the hospital, compared to $17 \%$ of the parents of full-term children.

Törölä et al. ${ }^{22}$ found that $47.37 \%$ of preterm infants presented qualitative difficulties in feeding, finding that it had a longer duration, it was more disorganized and both children and feeders were more impatient during this process.

According to Johnson et al. ${ }^{14}$, in relation to the report of parents, they found $14.9 \%$ of the children with a history of moderate or late prematurity had difficulties in feeding at 2 years old, compared to $9.5 \%$ of full-term children. This risk was only significant in the rejection/ selectivity aspects of feeding and oral motor problems.

Crapnell et al. ${ }^{13}$ report a higher percentage of feeding problems at 2 years old, finding a $23 \%$ of children who met the criteria of feeding difficulties, having twice the risk of feeding disorders compared to healthy full-term children at two years old, as reported by Carter et al. ${ }^{28}$. Crapnell et al. ${ }^{13}$ found negative emotions during the feeding process $(28 \%)$ and difficulty sleeping $(17 \%)$. It is noteworthy that in this study, $55 \%$ of parents described their children as "good eaters".

Neuwenhuis et al..$^{16}$ found that, at 3 years old, $11 \%$ of preterm infants had difficulty feeding. The latter is similar to what was mentioned by Jonsson et al. ${ }^{9}$, where $7.41 \%$ of the children presented feeding problems at 3 years old, as can be seen in Table 6 .

Table 6. Feeding difficulties in preterm infants in comparison to those of full-term infants

\begin{tabular}{|c|c|c|}
\hline Author & $\begin{array}{l}\% \text { of preterm infants with } \\
\text { feeding difficulties }\end{array}$ & $\begin{array}{l}\% \text { of full-term infants with } \\
\text { feeding difficulties }\end{array}$ \\
\hline Jonsson et al ${ }^{9}$ & $\begin{array}{c}48 \% \text { at discharge } \\
7.41 \% \text { at three years old }\end{array}$ & $17 \%$ at discharge \\
\hline Johnson et al ${ }^{14}$ & $14.9 \%$ & $9.5 \%$ \\
\hline Neuwenhuis et al ${ }^{16}$ & $11 \%$ at three years old & ---- \\
\hline
\end{tabular}


When reviewing literature, different difficulties related to the feeding process in preterm infants were found: presence of gag reflex, choking, delay in head and neck or postural control, nausea, rejection and selectivity of food along with crying and spitting food, among others.

As for the presence of gag reflex and choking during feeding, Rodrigues and Delgado found that $25 \%$ of the children presented them, similar to those reported by Crapnell et al. ${ }^{13}$, who found $34 \%$ of children with gag reflex and choking. In addition, Rodrigues and Delgado ${ }^{8}$ reported that preterm infants presented nausea $40.6 \%$ of the time. It should be noted that parents reported that $74 \%$ spit out the food, these being atypical behaviors in feeding according to what was found by Crapnell et al. ${ }^{13}$.

Chung et al. ${ }^{10}$ found significant differences between infants who were "prepared" in their development versus "unprepared" infants in relation to the following feeding characteristics: pushing food out $(p<.005)$, gagging $(P<.0001)$, maintaining food in the mouth ( $p$ $<.006)$, and crying $(p<.005)$. These characteristics may be seen as determinants for considering a child with or without feeding difficulties.

Migraine et al. ${ }^{17}$ reported in preterm infants a trend to have a lower food repertoire compared to full-term infants, which shows that this group presents more behavioral difficulties in relation to feeding. They also had less appetite and enjoyed their food less. Both neophobia and food selectivity tended to be higher in preterm infants but did not reach significance. He also reported that preterm infants consumed a smaller variety of foods and their diet tended to be more dairybased and potato-based, with fewer fruits and cereals, foods that required greater chewing control. The cause of these difficulties in preterm infants may be their immaturity, extended hospitalization, chronic illnesses, and prolonged exposure to unpleasant oral-tactile experiences and neurological impairments. All these factors favor an inappropriate response to tactile stimulation in the face and oral cavity, also occurring with flavors, temperature and texture, thus compromising their ability to feed adequately ${ }^{26}$.

In a study by den Boer and Schipper ${ }^{21}$ it was observed that at 9 months of corrected age, posture balance presented difficulties in $17 \%$ of preterm infants compared to $2 \%$ of full-term infants. They also reported that the most frequent problems in preterm infants were presence of choking (46\%) and gag reflex (55\%) during feeding. There were no significant differences between both groups in the presence of drooling.

Jonsson et al. ${ }^{9}$ reported that at the time of introducing solid foods in preterm infants' diet, $40 \%$ of them vomited, $30 \%$ did not accept all textures and $15 \%$ presented gag reflex during feeding, with a higher proportion than in full-term infants. The less tolerated texture in this group was lumpy food.

According to Crapnell et al. ${ }^{13}, 41 \%$ of children presented with food rejection and $25 \%$ of children tended to reject foods that require chewing. In the same research it is pointed out that in children with feeding problems hypotonia was found. Both results agree with what was observed by Coulthard et al. ${ }^{23}$, who mention that the ability to eat solid foods depends both on the experience of chewing and on the development of oral motor skills produced in the first year of life. This rejection, as pointed out by Crapnell et al. ${ }^{13,15}$ may also be due to what has been commented by McGrath et al. ${ }^{29}$, who point out that infants with long neonatal intensive care hospitalizations may associate feeding with pain and discomfort.

At two years old, the food repertoire of preterm infants would be smaller, showing greater behavioral difficulties related to feeding ${ }^{17}$. These differences would continue to be present, with preterm infants having twice the risk of feeding problems ${ }^{13,15}, 23 \%$ of them presenting with feeding difficulties, which would decrease at 3 years old to $7.41 \%-11 \%, 16,17$. In addition, parents report that there is a higher percentage of atypical behaviors during feeding, with rejection of foods that require chewing ${ }^{13}$ in accordance with the experience of chewing and the development of oral motor skills produced in the first year of life, rejection that McGrath et al. ${ }^{29}$ associate with hospitalizations and manipulations to which preterm children are subjected to at birth.

\section{Stress and parental knowledge regarding the feeding process}

Of the articles analyzed, five refer to the presence of parents' stress at the time of feeding 8,10,13,20,22.

Rodrigues and Delgado ${ }^{8}$ analyzed the degree of information of the parents regarding the introduction of feeding in their children, $75 \%$ reported having had some type of guidance in this matter.

One aspect to consider in parental stress during the feeding process is the development of their children. Chung et al. $^{10}$ found that at the time of introducing 
solid foods, parents of children with developmental "readiness" were more satisfied with their children's eating habits, felt more comfortable feeding them and less stressed and in turn they observed more appetite in their children. Somewhat similarly, Jonsson et al. ${ }^{9}$ reported that $67 \%$ of the parents of preterm infants were satisfied with their children's eating habits.

It is noteworthy that in Lucchi et $\mathrm{al}^{2}, 48 \%$ of preterm infants presented difficulties in feeding after discharge, so the level of information of the parents could be relevant both in the detection and management of these. The latter idea, regarding the importance of parental education, is reaffirmed by Parker et al. ${ }^{20}$.

Both aspects mentioned: the stress and degree of information of parents, seem to be a subject that needs to be more addressed, being of valuable interest. The World Health Organization and UNICEF consider essential that parents or caregivers of infants have the necessary and complete information regarding supplementary feeding to be successful, together with family and health personnel support ${ }^{30}$.

\section{CONCLUSION}

This review found a variety of assessment instruments and methodologies. That makes it difficult to generalize information regarding feeding in preterm infants and comparing studies conducted in this population, since using different instruments and assessment methodologies, the information is diverse and not very comparable.

The variety found among the researches is not only given by the different instruments used, but also by the age and observed aspects of the subjects. That is why it is difficult to compare and clearly establish the age of incorporation of solid foods and the development of feeding skills, showing that there is still no consensus on which instruments or procedures to use.

It would be interesting to investigate more in relation to this topic through longitudinal studies, since only 2 of the 12 researches reviewed were performed using this methodology. This would make it possible to emphasize or consider aspects that are not observed in cross-sectional studies.

The incorporation of solid foods was performed earlier in preterm than in full-term infants in the four studies which mentioned this aspect.

It is fundamental to know how the feeding process develops in preterm infants and what the main difficulties are. This information should not only fall on clinicians and researchers, but also on the parents of the children.

As for the development of feeding skills, preterm infants may show a different performance from birth, this being described by the parents. Although preterm infants showed a disorganized sucking pattern at the beginning compared to their full-term peers, the studies later differ in their findings.

There is a consensus in literature on the fact that preterm infants are at greater risk of presenting feeding difficulties.

In future research, the relation between the degree of information that the parents handle and the stress that they present could be analyzed, to learn if knowledge about the subject may influence the decrease or increase of stress.

There is no consensus on central aspects such as the age of incorporation of different types of consistencies in the feeding process, in full-term or preterm infants.

\section{REFERENCES}

1. OMS: Organización Mundial de la Salud [internet]. OMS; [20 julio 2016]. Nacidos Demasiado Pronto: Informe de acción global sobre nacimientos prematuros. Disponible en: http://www.who.int/pmnch/media/news/2012/ borntoosoon_execsum_es.pdf?ua=

2. Lucchi C, Bernardis KE, Ibidi SM, Olivan SC. Dietary transition difficulties in preterm infants: critical literature review. J Pediatr. 2015;92(1):7-14.

3. INE: Instituto Nacional de Estadística [internet]. Chile: INE; 2011 [20 julio 2016]. Estadísticas vitales: Informe anual 2011. Disponible en: http://www.ine. $\mathrm{cl} /$ canales/menu/publicaciones/calendario_de_ publicaciones/pdf/completa_vitales_2011.pdf

4. Brisque $F$, Rodrigues $C$. Sucção em recémnascidos pré-termo e estimulação da sucção. Pró-Fono R. Atual. Cient. 2006;18(2):141-50.

5. Buswell $\mathrm{CH}$, Leslie $\mathrm{P}$, Embleton ND, Drinnan MJ. Oral-motor dysfunction at 10 months corrected gestational age in infants born less than 37 weeks preterm. Dysphagia. 2009;24(1):20-5.

6. WHO: World Health Organization [internet]. Suiza: Kramer M, Kakuma R; 2002 [16 julio 2016]. The optimal duration of exclusive breastfeeding. Disponible en: http://whqlibdoc.who.int/hq/2001/ WHO_NHD_01.08.pdf 
7. Braid S, Harvey EM, Bernstein J, Matoba N. Early Introduction of Complementary Foods in Preterm Infants. JPGN. 2015; 60(6):811-8.

8. Rodrigues $\mathrm{H}$, Delgado SL. Characterization of the feeding development of preterm infants between three and twelve months. Rev CEFAC. 2014;16(3):917-27.

9. Jonsson M, Doorn JV, Van den Berg J. Parents' perceptions of eating skills of pre-term vsfull-term infants from birth to 3 years. International Journal of Speech-Language Pathology. 2013;15(6):602-12.

10. Chung J, Lee J, Spinazzola R, Rosen L, Milanaik R. Parental perception of premature infant growth and feeding behaviors: use of gestation-adjusted age and assessing for developmental readiness during solid food introduction. Clin Pediatr. 2014;53(13):1271-7.

11. MINSAL: Ministerio de Salud [internet]. Santiago de Chile: Departamento de Nutrición y ciclo vital Minsal; [20 julio 2016]. Guía de Alimentación del Niño(a) Menor de 2 años. Available from: http:// www.nutricion.sochipe.cl/subidos/catalogo3/Guia_ Alimentacion.pdf

12. Castillo-Duran $C$, Balboa $P$, Torrejón $C$, Bascuñan K, Uauy R. Alimentación normal del niño menor de 2 años. Rev chil pediatr. 2013;84(5):565-72.

13. Crapnell TL, Rogers CE, Woodward MD, Neil JJ, Pineda RG. Factors associated with infant feeding difficulties in the very preterm infant. Acta Paediatr. 2013;102(12):539-45

14. Johnson S, Matthews R, Draper ES, Field DJ, Manktelow BN, Marlow $\mathrm{N}$ et al. Eating difficulties in children born late and moderately preterm at 1-3 $2 \mathrm{y}$ of age: a prospective population-based cohort study. The american Journal of clinical nutrition. 2016;103(2):406-14.

15. Crapnell TL, Woodward LJ, Rogers CE, Inder TE, Pineda RG. Neurodevelopmental profile, growth, and psychosocial environment of preterm infants with difficult feeding behavior at age 2 years. The Journal Of Pediatrics. 2015;167(6):1347-53.

16. Nieuwenhuis T, Verhagen EA, Bos AF, Van Dijk MW. Children born preterm and full term have similar rates of feeding problems at three years of age. Acta Pediatrica. 2016;105(10):e452-e457.

17. Migraine A, Nicklaus $S$, Parnet $P$, Lange $\mathrm{CH}$, Monnery-Patris $\mathrm{S}$, Des Robert $\mathrm{C}$ et al. Effect of preterm birth and birth weight on eating behavior at 2 y of age. Am J Clin Nutr. 2013;97:1270-7.
18. Arvedson J, Brodsky L..Pediatric swallowing and feeding: Assesment and management. $.2^{\circ}$ edición. Canadá: Singular Thomson Learning:2002.

19. Morris E, Klein M. Pre Feeding Skills. $2^{\circ}$ edición. San Antonio TX.: Therapy Skill.

20. Builders, A Harcourt Health Sciences Company.; 2000.

21. Parker M, Rybin D, Heeren TC, Thoyre SM, Corwin MJ. Postdischarge feeding interactions and neurodevelopmental outcome at 1-year corrected gestational age. The Journal Of Pediatrics. 2016;174:104-10.

22. Den Boer SL, Schipper JA. Feeding and drinking skills in preterm and low birth weight infants compared to full term infants al a corrected age of nine months. Early Human Development. 2013; 89:445-7.

23. Törölä $H$, Lehtihalmes $M$, Yliherva $A$, Olsén $P$. Feeding skill milestones of preterm infants born with extremely low birth weight(ELBW). Infant Behavior and Development. 2012;35:187-94.

24. Coulthard H, Harris G, Emmett P. Delayed introduction of lumpy foods to children during the complementary feeding period affects child's food acceptance and feeding at 7 years of age. Maternal and Child Nutrition. 2009;5:75-85.

25. Macias S, Rodríguez S, Roynayne de Ferrer P. Patrón de alimentación e incorporación de alimentos complementarios en lactantes de una población de bajos recursos. Rev chil nutr. 2013;40(3):235-42.

26. Vásquez E, Romero E, Larrosa $A$, Machado A. Recomendaciones para la alimentación del niño durante los primeros 23 meses de vida. Pediatría de México. 2012;14(1):25-42.

27. Campos-Montero Z. Problemas de la alimentación en lactantes. Segunda parte: Fases oral y faríngea. Acta pediátr costarric. 2010;22(1):14-22.

28. Soares JPO, Novaes LFG, Araújo CMT, Vieira ACC. Natural breastfeeding of pre- term newborns from the perspective of the mother: an integrative review. Rev. CEFAC. 2016;18(1):232-41.

29. Carter AS, Briggs-Gowan MJ, Jones SM, Little TD. The infant-toddler social and emotional assessment (ITSEA): factor structure, reliability, and validity. J Abnorm Child Psychol. 2003;31:495-514.

30. McGrath A, Schurle A, C Mangiaracina, Schulz $\mathrm{T}$, Hyman P. Moving from tube to oral feeding in medically fragile nonverbal toddlers. j Pediatr Gastroenterol Nutr. 2009;49(2):233-6. 
31. WHO: World Health Organization [internet]. Genebra: WHO; 2003 [16 julio 2016] Estrategia mundial para la alimentación del lactante y del niño pequeño. Disponible en: http://www.who.int/ nutrition/publications/gs_infant_feeding_text_spa. pdf. 